\title{
More Than Meets the Eye: Volcanic Hazard Map Design and Visual Communication
}

\author{
Mary Anne Thompson (1), Jan M. Lindsay \\ and Graham S. Leonard
}

\begin{abstract}
Volcanic hazard maps depict areas that may be affected by dangerous volcanic processes, such as pyroclastic density currents, lava flows, lahars, and tephra fall. These visualisations of volcanic hazard information are used to communicate with a wide variety of audiences both during times of dormancy and volcanic crisis. Although most volcanic hazard maps show similar types of content, such as hazard footprints or zones, they vary greatly in communication style, appearance, and visual design. For example, maps for different volcanoes will use different combinations of graphics, symbols, colours, base maps, legends, and text. While this variety is a natural reflection of the diverse social, cultural, political, and volcanic settings in which the maps are created, crises and past work suggest that such visual design choices can potentially play an important role in volcanic crisis communication by influencing how people understand the hazard map and use it to make decisions. Map reading is a complex process, in which people construct meaning by interpreting the various visual representations within the context of their information needs, goals, knowledge, and experience. Visual design of the map and the characteristics of the hazard map audience can therefore influence how hazard maps are understood and applied. Here, we review case studies of volcanic crises and interdisciplinary research that addresses the relationship between hazard maps, visual design, and communication. Overall,
\end{abstract}

M.A. Thompson $(\varangle) \cdot$ J.M. Lindsay

School of Environment, University of Auckland,

Private Bag 92019, Auckland, New Zealand

e-mail: m.thompson@auckland.ac.nz

J.M. Lindsay

e-mail: j.lindsay@auckland.ac.nz

G.S. Leonard

GNS Science, P.O. Box 30-968, Lower Hutt 5040,

New Zealand

e-mail: g.leonard@gns.cri.nz

Advs in Volcanology (2018) 621-640

https://doi.org/10.1007/11157_2016_47

(C) The Author(s) 2017

Published Online: 15 March 2017 
this growing body of work suggests that volcanic hazard maps can be very useful visual tools for crisis communication if they are designed in a way that provides clear and useful information for the audience. Further, while it is important that each map is designed for its unique situation and setting, engaging with hazard map audiences to better understand their information needs and considering lessons learnt from interdisciplinary work on visual communication can help inform and guide knowledge exchange using maps.

\section{Introduction}

As a volcanic crisis begins to unfold, demand for information about when and where dangerous volcanic hazards might impact increases. A key medium for communicating this information is a volcanic hazard map - a visual, spatial depiction of where volcanic phenomena might occur within a certain time frame. While hazard maps play a role in managing many elements of a volcanic crisis, such as understanding relationships between hazards, identifying areas of potential danger, informing risk assessments, and planning evacuation routes, they serve as an important tool in crisis communication.

We live in an increasingly visual society, where most of us see and process images more than we read words (Lester 2014). In many cases, images can attract visual attention (Carrasco 2011), trigger information-processing (Domke et al. 2002), stimulate emotional response (Mould et al. 2012; Lester 2014), and influence decision-making (Tufte 1997; Daron et al. 2015) more than other types of media. Images can be concisely delivered in many different formats, through many different channels, and can communicate across lexical and linguistic boundaries. Hazard maps are common images used by scientists to communicate information about volcanic hazards with a wide range of audiences. These maps, and the inferences and responses that they elicit, become particularly important during crisis situations when they may become read and circulated widely. During such high-stakes, high-pressure situations, people tend to rely more on their initial impressions and intuitive feelings about hazard and risk than on exhaustive analytical evaluation of hazard and risk information (Finucane et al. 2000). Accordingly, the way that a hazard map captures visual attention and conveys affective meaning could have a significant impact on decisions made during a volcanic crisis. It is therefore important to understand how people interact with hazard map images, and how visual communication processes influence the messages that audiences take away.

Volcanic hazard maps are created by scientists across the world, using a number of different types of datasets, methodologies, and approaches (Calder et al. 2015). For example, a map could show only one volcanic hazard (e.g., ash fall), or multiple volcanic hazards (e.g., ash fall, lava flow, and ballistic ejecta). These hazards may be depicted as intensities (e.g., centimetres of ash that are likely to accumulate) or as a set of nested or cumulative zones (e.g., high, medium, and low hazard zones). The hazard map may be based on observation of past volcanic hazard deposits, probabilistic hazard modelling, simulation of a particular hazard scenario, or information drawn from an analogue volcano. The high degrees of freedom mean that volcanic hazard maps can represent many different types of information. In reviewing 120 volcanic hazard maps from around the world, Calder et al. (2015) identify five different hazard map "types" which describe these various combinations: geology-based maps, integrated qualitative maps, administrative maps, modelling-based maps, and probabilistic maps (Fig. 1). The classification provides a way to categorise and consider the types of 
inputs used in developing volcanic hazard maps around the world. The way that these inputs are visualised into a final map design output are similarly diverse.

Volcanic hazard maps are traditionally created by the scientists who carry out volcanic hazard assessments. Visual design of a hazard map is therefore typically governed by factors such as the specific methodology used, common scientific and cartographic practice at the time, status of volcanic activity, social and cultural setting, and local agency standards or policy requirements in place. Variation in these factors over time and place has resulted in the vastly different layouts, formats, colour schemes, data representations, symbology, and hazard map styles being used around the world today. While this visual diversity reflects important and unique differences in map purpose and social and volcanic setting, past crises and research over the last few decades have highlighted that such visual design choices can also carry great importance for communication, as they may influence how different audiences interpret the map and use it to make decisions regarding hazard and risk.

Maps communicate more than meets the eye. Each reader individually constructs meaning from the map through visual cognition and interpretation of the various symbols, colours, shapes, and text within the context of his or her prior knowledge and experience (MacEachren 1995; Perkins et al. 2011). Map reading is thus a (a) Geology-based

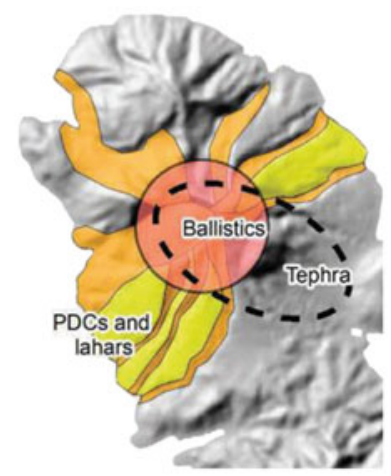

(d) Probabilistic

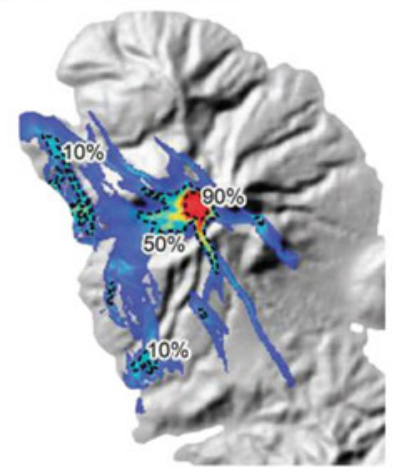

(b) Integrated qualitative

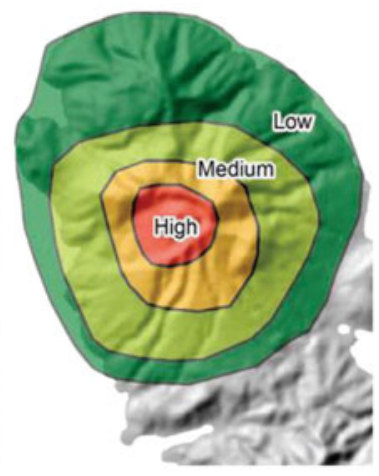

(e) Administrative

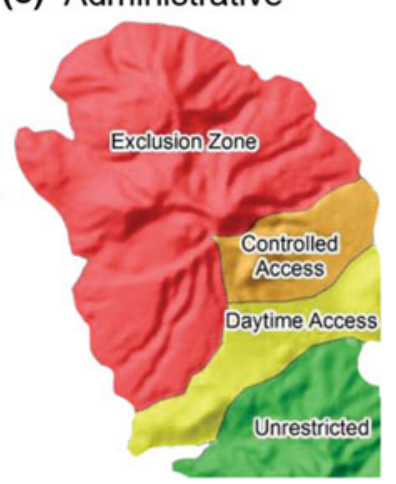

Fig. 1 Hypothetical examples of the five types of volcanic hazard map identified by Calder et al. (2015). Each map type represents a different type of input information: a geology-based maps, the most common type of volcanic hazard map, are based on hazard footprints of past events; b integrated qualitative maps are based on amalgamation of many different types of

\section{(c) Modelling-based}

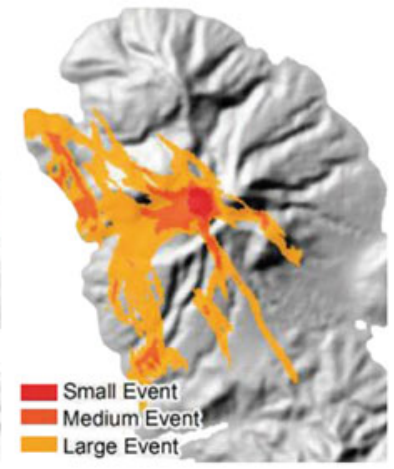

hazard information; c modelling-based maps are based on simulation of certain hazard scenarios; d probabilistic maps are based on probabilistic assessment of hazards; and e administrative maps are based on both hazard information but also on emergency management and administrative information. Modified from Calder et al. (2015) 
complex information-processing exercise, and visual design and audience background can have a strong effect on the messages that people take away (Robinson and Petchenik 1976; Bertin 1983; MacEachren 1995; Monmonier 1996; Lloyd 2011; Perkins et al. 2011). During a crisis, hazard maps can become widely distributed and used for communicating with many different audiences. In these rapid mass communication contexts, audiences may not always consult supporting resources beyond the map image itself (e.g., Leonard et al. 2014). In such contexts, it is important to consider how visual design and communication factors influence hazard map reading, knowledge exchange, and decisionmaking. Here, we draw upon case studies and past work to review how volcanic hazard maps are used to visually communicate with difference audiences, and how visual design plays a role in this communication.

\section{Visual Communication}

Volcanic hazard maps synthesize a wealth of information about individual processes and interdependent phenomena over a range of spatial and temporal scales. As with all cartographic representations, a number of generalisations therefore have to be carried out in order to visually communicate this complex data in a clear and concise way in two dimensions. This often requires simplifying complicated physical and numerical concepts, such as particle and flow dynamics and probabilistic uncertainty. Deciding upon the most salient and useful content, and the clearest and simplest way to display that content, is a challenging, but important task. Highly complex maps are often difficult for most audiences to understand (MacEachren 1982). However, past crises and work have shown that engaging with audiences to understand the way that they perceive hazards can help guide generalisation of complex content and inform communication approaches.

\subsection{Communicating Complex Content}

On 13 November 1985, after a year of awakening, but with little short-term warning, the ice-capped volcano Nevado del Ruiz erupted. The eruption sent devastating lahars - turbulent mixes of snow, ice, meltwater and pyroclastic debris - down valleys and channels to the Colombian town of Armero, causing one of the worst volcanic disasters in history (Pierson et al. 1990). The Nevado del Ruiz tragedy was the result of a complex interplay between a number of technological, political, and social circumstances (Voight 1990). However, retrospective accounts recall the "state of frustration and confusion" (Voight 1990, p. 180) that arose from a "poorly understood" (Parra and Cepeda 1990, p. 117) hazard map (Fig. 2a). Although a revised hazard map was being prepared, the lahars struck two days before the planned release of the new map. Although the available map showed overall accurate content, it was displayed using scientific and probabilistic concepts that were unfamiliar to many map audiences, leading to miscommunication among authorities, the media, and the public (Parra and Cepeda 1990; Voight 1990).

In 1990, the post-event hazard map was simplified by replacing individual probabilistic hazard paths with generalized hazard zones (high, moderate, and low) (Parra and Cepeda 1990). The revision aimed to develop a map that was "easily comprehensible to non-specialists and therefore less susceptible to misinterpretation" (Parra and Cepeda 1990, p. 117). Today, the most recent Nevado del Ruiz hazard map (SGC 2015; Fig. 2b) continues this generalisation approach. Efforts to design an "intuitive" (Parra and Cepeda 1990, p. 117) map for non-scientific audiences acknowledged the important crisis communication role of volcanic hazard maps and brought attention to the importance of considering audience perspectives in designing maps. The experience led to reflection about hazard map design in other volcanically active parts of 


\section{(a) Nevado del Ruiz hazard map October 1985}

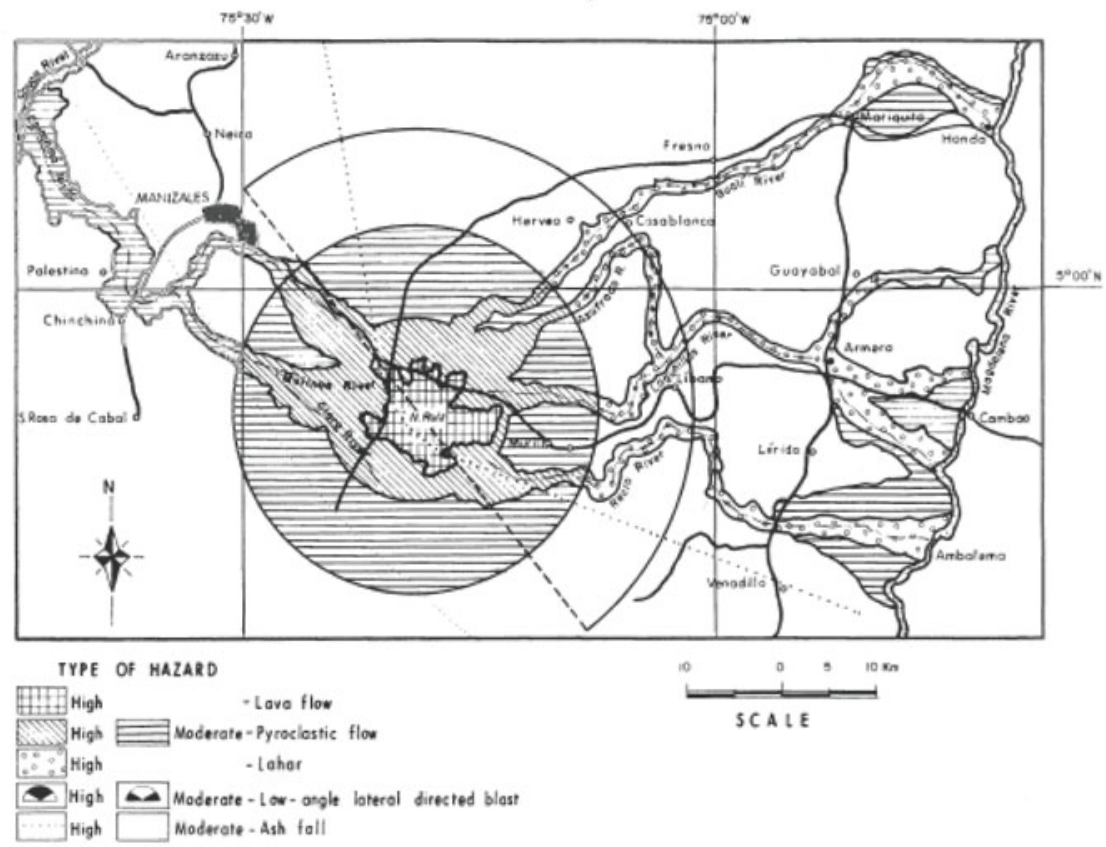

(b) Nevado del Ruiz hazard map 2015

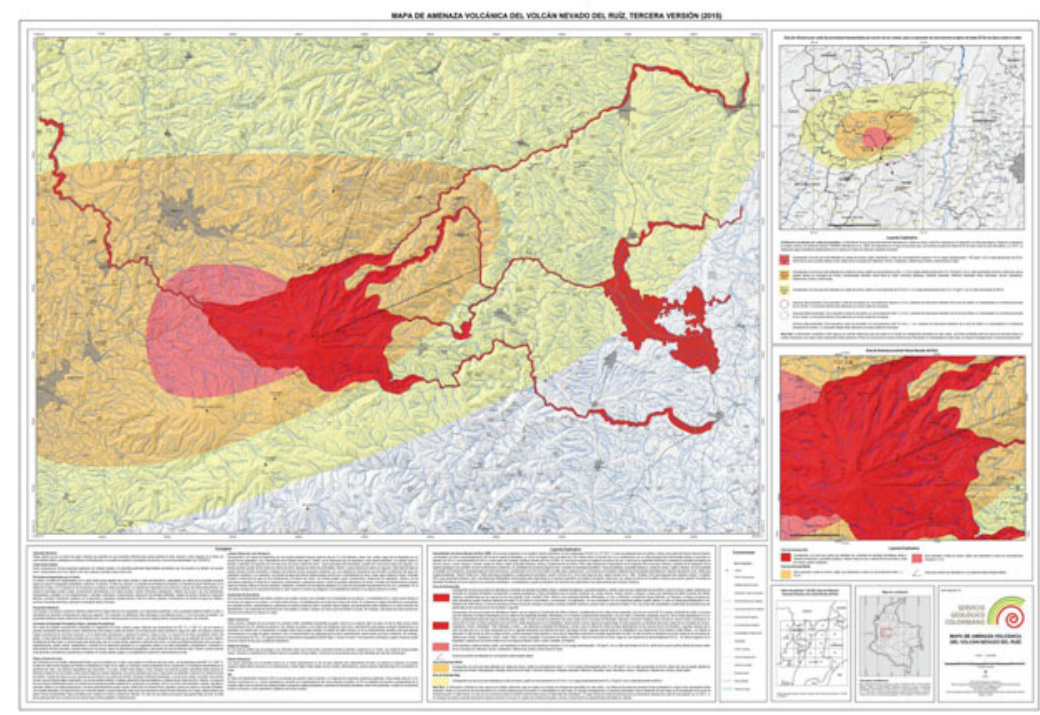

Fig. 2 Evolution of the volcanic hazard map for Nevado del Ruiz, showing a a simplified black-and-white version of the hazard map that was available during the time leading up to the November 1985 crisis (modified from
Parra and Cepeda 1990), and b the current, revised hazard map produced by the Colombian Geological Survey in 2015 (SGC 2015) 
the world. For example, Nakamura et al. (2008) note that the crisis sparked an evaluation of Japanese volcanic hazard maps, resulting in a design change "from being specialist-oriented to being designed to be more easily understood" (p. 297).

The value of having simple and clear hazard maps for use in crisis communication has emerged in a number of other volcanic crises, including the eruption crisis on the Caribbean island of Montserrat. On 18 July 1995, a small phreatic explosion on Soufrière Hills volcano marked the start of an eruption that would go on to continue for nearly two decades. Episodes of andesitic dome-building and collapse produced rapid, hot pyroclastic flows that devastated nearly two-thirds of the island (Aspinall et al. 2002). The people of Montserrat were badly affected by the disaster. More than $90 \%$ of the population was displaced, and communities suffered ongoing distress and uncertainty (Kokelaar 2002; Sword-Daniels et al. 2014). Over the course of the eruption, hazard maps and risk management maps were widely used in communication with authorities and local communities (Aspinall et al. 2002).

In an effort to minimise disruption and keep as much land open to utilisation as possible, early maps used a microzonation approach, where the island was divided into seven different zones reflecting gradual levels of risk, from A (more risk) to $\mathrm{G}$ (less risk) (Aspinall et al. 2002; Kokelaar 2002; Fig. 3a). Microzones were tied to (a) Montserrat microzonation map November 1996

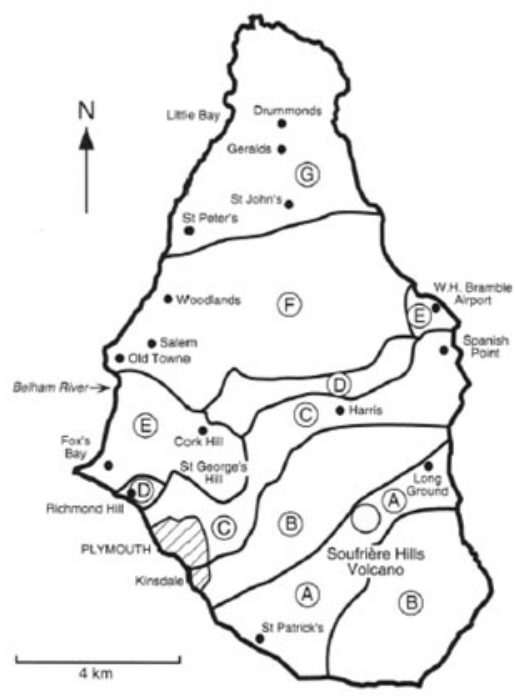

(b) Revised Montserrat map September 1997

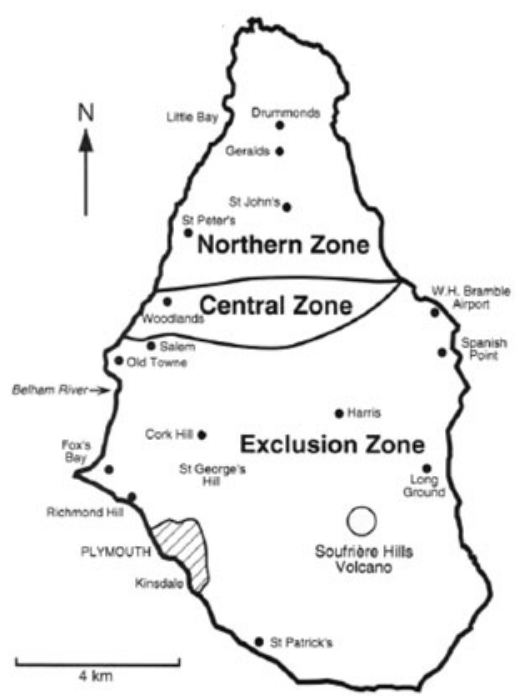

(c) Examples of aerial and perspective photos of Montserrat tested in Haynes et al. (2007)

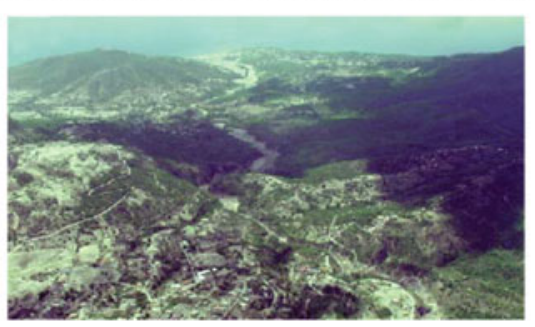

Fig. 3 Black-and-white versions of maps used to communicate with the public during the Soufrière Hills eruption crisis on Montserrat in a November 1996 and b September 1997 (modified from Kokelaar 2002); and

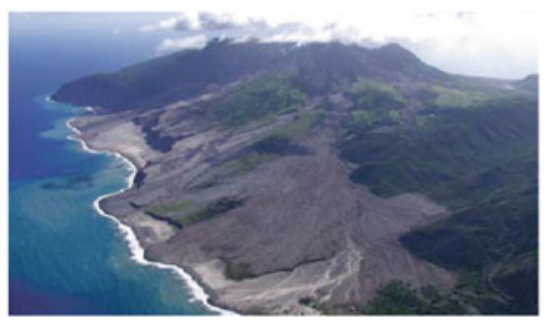

c examples of the aerial and perspective photographs of Montserrat, which were easier for participants to read and use than plan view maps (modified from Haynes et al. 2007) 
access restrictions, which varied based on changes in an associated volcanic alert level system. However, the complex maps, together with their dynamic relationship to alert levels, were sometimes found to be "difficult to communicate to the public" (Kokelaar 2002, p. 12). Alert levels alone can be complex concepts to communicate (Fearnley et al. 2012; Potter et al. 2014). Recognising a need to simplify the maps for visual communication purposes, later versions of the map (September 1997 onwards) generalised the microzones into two to three larger zones representing different levels of access, including an exclusion zone around the volcanic edifice (Fig. 3b). The responsive change illustrated an audience-driven shift in map design, but also highlighted the challenges associated with communicating complex and interdependent content about hazard and risk.

While the Montserrat experience highlighted the importance of considering how key volcanic hazard and risk information is generalised and displayed on a map, Haynes et al. (2007) found that other fundamental elements of hazard map design can also play a role in crisis communication. Haynes et al. (2007) developed several different versions of the Montserrat hazard and risk maps that utilised a variety of different visual formats. They found that visual design elements, such as the choice of base map, influenced how local audiences used and understood the information. For example, participants were able to better identify spatial features and orient themselves with the information when it was portrayed on aerial or perspective photographs (Fig. 3c). While plan view or topographic contour maps may be an intuitive choice for an earth scientist, it may not be the most suitable choice for communicating spatial hazard information with other audiences (Haynes et al. 2007). Nave et al. (2010) found similar results in a study of Stromboli volcano hazard map styles, recommending plan view contour hazard maps for government officials, but perspective displays for non-specialist audiences. Collectively, these, and many other past volcanic crises have contributed valuable knowledge about the ways that different audiences respond to certain hazard visualisation approaches and how this may influence crisis communication efforts.

\subsection{Considering Audience Perspectives}

In order to share valuable and useful knowledge about a hazard or risk with an audience, it is first important to understand the audience's existing knowledge and perspectives regarding the hazard or risk, and what information is valued and needed (Bostrom and Löfstedt 2003; Perry et al. 2016). The way that different audiences perceive volcanic hazard and risk can have an important influence on how they respond to hazard and risk communication efforts (Johnston et al. 1999; Paton et al. 2008; Gaillard and Dibben 2008; Doyle et al. 2014). Engaging with hazard map audiences to better understand their existing knowledge and perceptions of volcanic hazard and risk can therefore help guide and inform approaches to hazard and risk communication, including hazard map design. Integrative engagement with audiences can also facilitate constructive dialogue about volcanic hazards and help engender trust in the resulting maps and communication products (Cronin et al. 2004; Haynes et al. 2008; Leone and Lesales 2009; Pierson et al. 2014).

Audience perception of volcanic hazards played a key role in the redesign of the volcanic hazard maps for Mt. Ambae, the largest active volcano of the Pacific island nation of Vanuatu. Cronin et al. (2004) found that the existing scientific volcanic hazard map (Fig. 4a) was poorly understood by most people living near the volcano because of differences in the ways that the scientists and local communities perceived hazardous volcanic phenomena. In order to create a hazard map design which better aligned with audience perspectives, the scientists engaged with the local communities to better understand how locals viewed and conceptualised volcanic hazard. The hazard map was then revised to assimilate both local and scientific worldviews. For example, while scientists and locals believed the 


\section{(a) Mt. Ambae volcanic hazard map 1995}

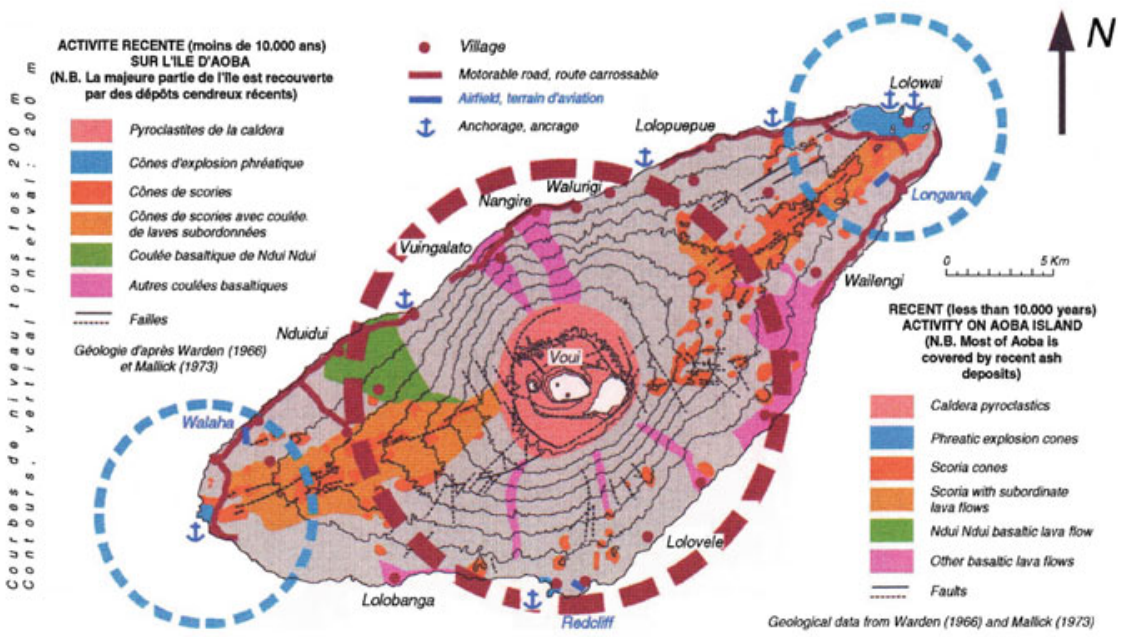

\section{(b) Revised Mt. Ambae hazard map Cronin et al. 2004}

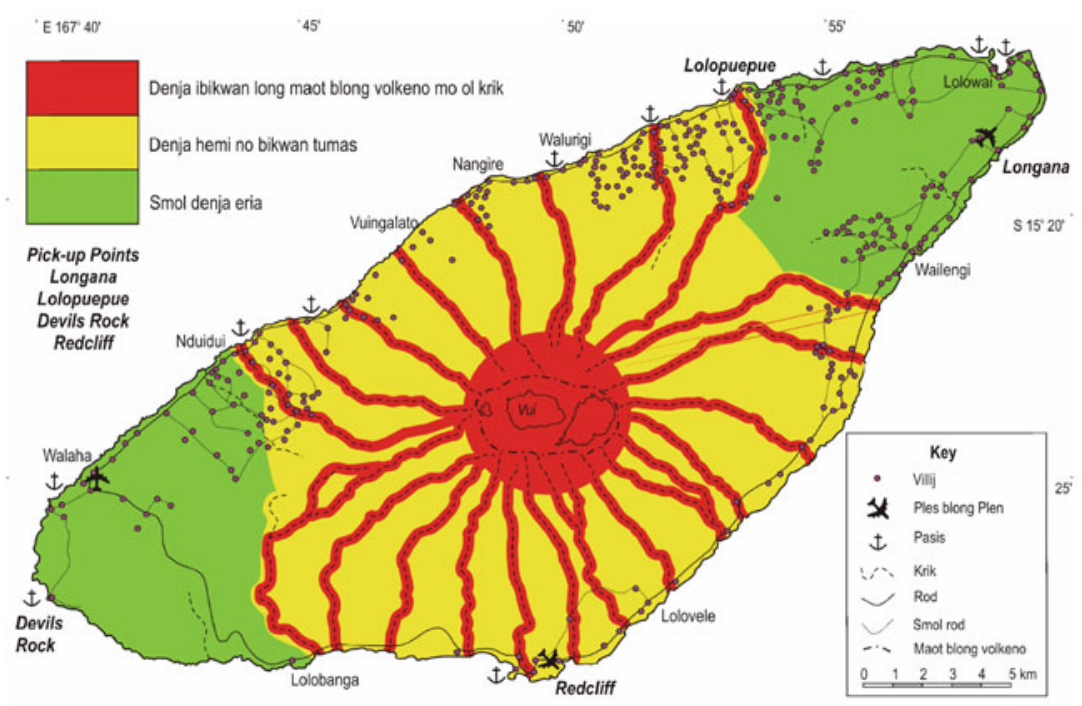

Fig. 4 Volcanic hazard maps for Mt Ambae. a The former scientific-style hazard map (modified from Monzier and Robin (1995)), and b The revised hazard map, which was developed through engagement with

summit area of the volcano was dangerous for different reasons, both groups acknowledged that the summit crater was a highly dangerous place. Similarly, although the scientists and locals believed in different causes of lahars, valleys were seen as particularly dangerous areas by both communities, and represents an integration of both local, traditional perspectives and outside, scientific perspectives (modified from Cronin et al. 2004)

groups (Cronin et al. 2004). The resulting map (Fig. 4b) represents a visual integration of both traditional and outside scientific worldviews about hazardous volcanic areas, and is an example of the how engagement can help achieve common ground for visual communication. 
While technical scientific hazard maps are still an essential tool for certain specialist tasks and stakeholders, different types of hazard map content may be prioritised for communication with other audiences who visit, work, and live in volcanic areas. For example, engagement with audiences in outdoor recreation areas near volcanoes in New Zealand and the United States has led to an emphasis on including life safety advice on volcanic hazard maps to share knowledge about what to do in the event of volcanic activity. Ruapehu is an active volcano in New Zealand with ski fields located on its summit and flanks. Annual engagement with audiences on the ski slopes has been used to guide visual design and content of the volcanic hazard map posters displayed in ski areas on Ruapehu (Leonard et al. 2008). The hazard maps are tailored specifically for winter sport audiences, illustrating valley areas exposed to lahar hazard and providing advice about how to evacuate valleys in the event of an eruption. Engagement with local audiences also led to integration of preparedness and evacuation advice into large interpretive outdoor signs about volcanic hazards for volcanoes of the Cascade Range in the United States, such as Mount Baker, Glacier Peak (Eske et al. 2015), and Mount Rainier (Schelling et al. 2014) (Cadig et al. this volume, Driedger et al. in prep). Combining volcanic hazard maps with supporting information about hazard phenomena and advice for increasing personal response capacity may encourage engagement and elaboration with hazard map information among some audiences (Paton 2003; Rakow et al. 2015). Although engaging with audiences can be time and resource intensive, carrying out work to understand audience perspectives in times of dormancy may prove useful in times of crisis communication.

In 2012, consideration of audience communication needs became a key consideration during response to the Te Maari eruption crisis at the Tongariro Volcanic Centre (TgVC) in New Zealand. While the Te Maari eruption was altogether small in scale, consisting of two phreatic explosions several months apart (Jolly et al. 2014a), it generated a high level of stress and uncertainty surrounding a potential increase in volcanic risk. The eruption vents were located within $2 \mathrm{~km}$ of New Zealand's most popular day track, the Tongariro Alpine Crossing, which averages up to 1500 visitors a day during the peak summer season. The $\mathrm{TgVC}$ is also a complex stratovolcano system capable of much larger, sub-Plinian eruptive activity (Moebis et al. 2011; Jolly et al. 2014b). While there was an existing series of background hazard maps that were designed for communicating with non-specialist audiences (Fig. 5a) (Leonard et al. 2008, 2014), the eruption meant that a new, event-focussed, crisis hazard map needed to be developed rapidly in order to provide information and life-safety advice directly related to the activity unfolding at the Te Maari vents (Fig. 5b).

Developing an audience-focussed hazard map under the stress and time pressures of a crisis situation was complex and taxing. Leonard et al. (2014) note that between the first and second versions of the map "at least 147 emails were sent by 23 different people across 9 different agencies and groups over a 24 day period" (p. 219). These numbers reflect the high level of engagement and interaction between various groups involved in management of the crisis, but also the complicated nature of rapidly compiling, synthesizing, and deciding on the content, messaging, and design of a hazard map during a crisis. The rapid, high-stakes nature of volcanic crises means that there are often limited resources to dedicate towards revising hazard map design during an actual event. During the Te Maari crisis, the relationships formed through past engagement were valuable in facilitating map development and design (Jolly et al. 2014b; Leonard et al. 2014). For example, one of the main populations affected by the event was a local indigenous group who provided valuable feedback into the final map design style (Leonard et al. 2014). In addition, the team relied heavily on resources that had been pre-prepared, emphasising the value in planning and considering approaches to map design during times of dormancy. 
(a) Background hazard map TgVC 2005

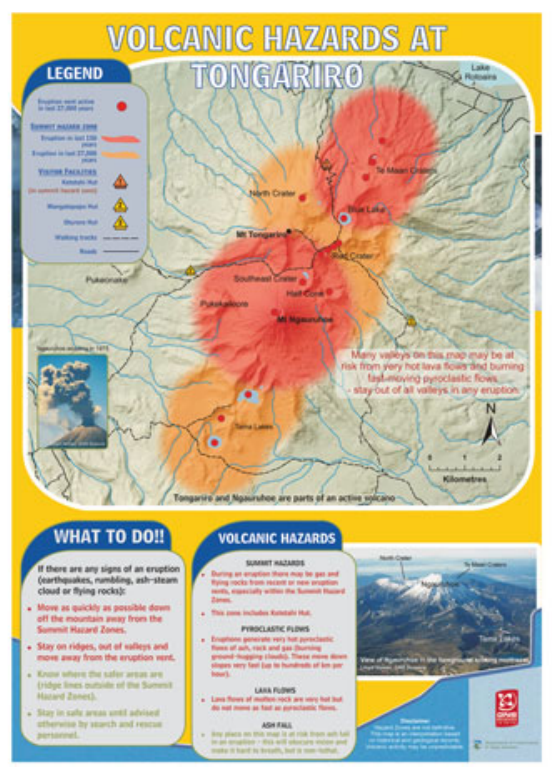

Fig. 5 Tongariro Volcanic Centre volcanic hazard maps for a typical background levels of activity (GNS Science 2005) and b during the Te Maari eruption crisis in 2012 (GNS Science 2012). Background hazard maps are long-term maps that are used to communicate potential

A number of lessons regarding crisis hazard maps emerged from the Te Maari experience, including the value of using version numbers, disclaimers, and providing metadata, and these are put forth as a set of recommendations by Leonard et al. (2014) (p. 225). In this list, they note the importance of considering the visual design of the map image itself. While the map images were presented with legends, descriptive text, and explanatory information, a number of media outlets clipped away this accompanying documentation and context when circulating and disseminating the map. Accordingly, in some cases, interpretation of the hazard map information relied almost wholly on the map image alone (Leonard et al. 2014).

\section{Visual Design}

Communicating with map images relies on visual perception and cognition. The map reader's eyes must sense and interpret visual variables such as (b) Crisis hazard map Te Maari 2012

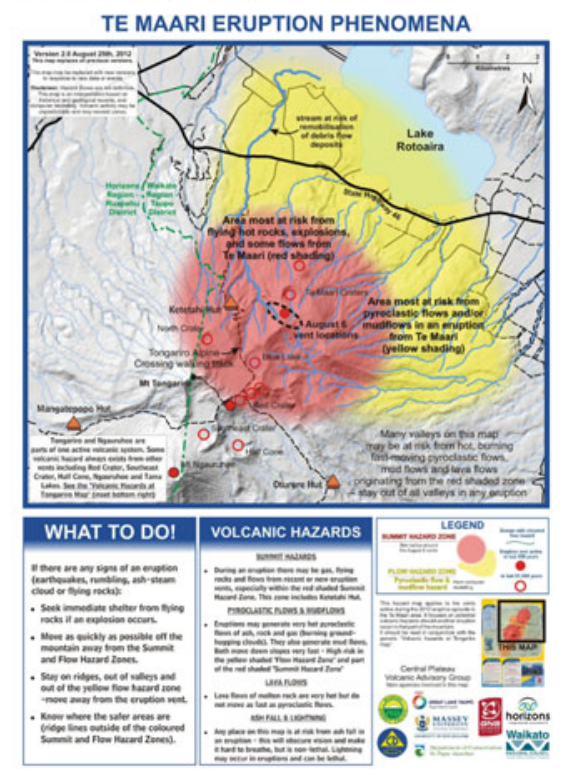

hazards during times of volcanic dormancy, while crisis hazard maps are temporary event-specific maps that are developed in response to imminent hazards (modified from Leonard et al. 2014)

shape, size, colour, texture, and orientation, and then cognitively process this information to create meaning (Bertin 1983; MacEachren 1995; Perkins et al. 2011). Well-designed visualisations can augment and enhance this cognitive processing by reducing cognitive load and facilitating inductive reasoning (Hegarty 2011; Patterson et al. 2014). Accordingly, visual map products have been found to improve comprehension of hazard information when compared to non-visual communication formats such as text and tables (Severtson and Vatovec 2012; Cheong et al. 2016; Cao et al. 2016). However, there are many variables to consider when visually designing a map, and it can often be difficult to determine which combination of variables will support cognition and reasoning. Further, map designs which are aesthetically appealing or intuitively preferred by map makers and users are not necessarily the most effective for decision-making tasks (Hegarty et al. 2009; Mendonça and Delazari 2014). Engaging with map audiences and carrying out empirical research into how people 
read and process map information can help confront these challenges by giving insight into the ways that different variables in visual design influence communication and decision-making. In addition, experimenting with innovative map visualisation formats can help also help create new ways of capturing audience attention and facilitating engagement with hazard information.

\subsection{Exploring and Testing Different Designs}

Research surrounding information visualisation is carried out in many different disciplines, including human computer interaction, human factors, cognitive psychology, semiotics, visual analytics, graphic design, cartography, and geovisualisation. Across these fields, a simple method used for evaluating the effectiveness of visual designs is to test how audiences perform in task-based exercises using different visualisations. However, in order test effectiveness, a defined, measurable communication goal needs to be identified (MacEachren 1982), and in the case of volcanic hazard maps, this can often be multidimensional and nuanced. Accordingly, Haynes et al. (2007) propose a mixed methods approach for evaluating volcanic hazard map design that combines quantitative performance evaluations with qualitative investigations. Using this approach, Haynes et al. (2007) were able to capture the complexity of how local audiences engaged with volcanic hazard and risk maps on Montserrat.

Thompson et al. (2015) adopted a similar mixed methods approach to explore the influence of visual design on volcanic hazard map communication in New Zealand. Thompson et al. (2015) took one dataset, which showed the probability of accumulating volcanic ash in the event of a hypothetical eruption, and displayed it using several different visual design variables. More than 100 scientists and organisational stakeholders (e.g., emergency managers, government officials) in New Zealand responded to quantitative and qualitative survey questions about the volcanic ash hazard using the different maps. The results showed that changing visual design elements, such as the data classification style or colour scheme, can have a significant effect on the way people understand the hazard. For example, participants were more accurate in quantitatively estimating the average probability of accumulating $1 \mathrm{~mm}$ of ash when they used a map that classified hazard data into discrete zones of probability (e.g., 5-14, 15-24 ... 65$75 \%$ ) compared to a map that classified the data using gradational shading (Fig. 6a, b). Participants were most precise when these two approaches were combined, with discrete probability isarithms (e.g., 15, 25 .. 65\%) overlain onto a gradational shading classification (Fig. 6 c). Participants also had strong feelings about the user-friendliness of the different maps styles. Map which were easier to read were associated with increased confidence in ability to use and apply the hazard information. The findings suggest that simple choices in data classification could have a significant influence on the way people understand, interpret, and apply probabilistic hazard information (Thompson et al. 2015).

Thompson et al. (2015) also conclude that it is important to consider colour scheme choices when representing volcanic hazard information on a map. Colour is an important visual design variable, which can guide attention, emotional response, and interpretation of map features (Robinson 1967; Bertin 1983; Wolfe and Horowitz 2004). However, the strong connotations and meaning that colours often carry for map readers introduces potential for miscommunication (Monmonier 1996; Brewer 1994). For example, Thompson et al. (2015) found that using a red-to-blue diverging-hue colour scheme (Fig. 7a) communicated a qualitatively different type of message than a red-to-yellow sequential-hue colour scheme (Fig. 7b). Participants tended to make interpretations about hazard state (presence/absence) when reading the diverging colour scheme map, but tended to 
(a) Gradational shading

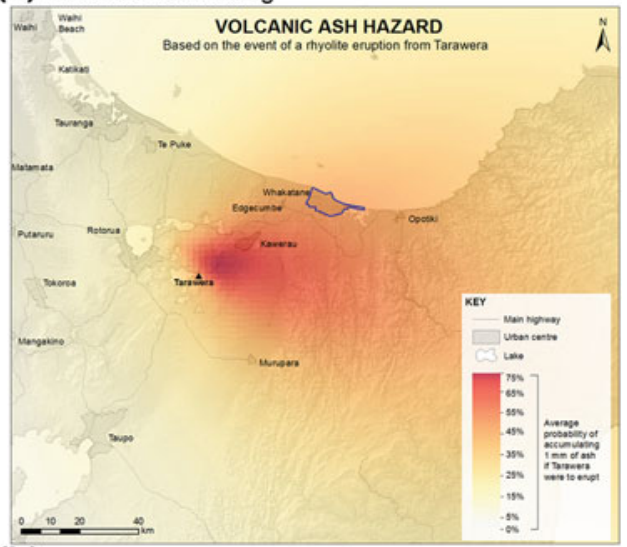

(b) Binned / Zoned

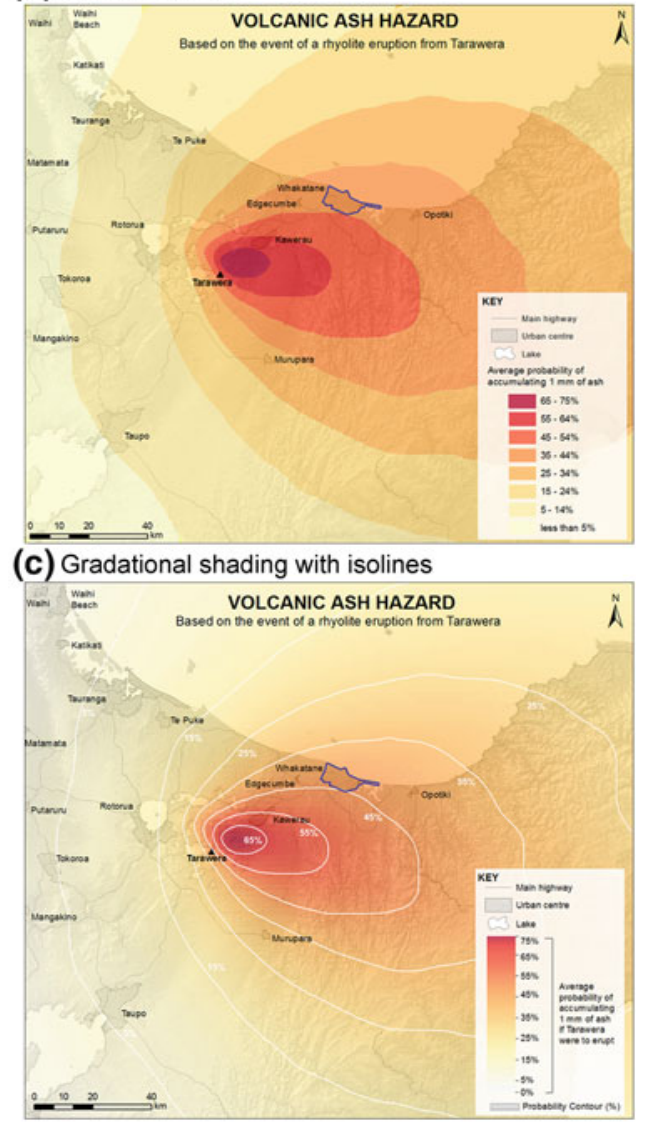

Fig. 6 Three types of probabilistic volcanic hazard map data visualisations tested by Thompson et al. (2015). Participants struggled to read accurate probability values for the area outlined in blue when using a a gradational shaded data classification. Participants performed better using $\mathbf{b}$ a binned (zoned) data classification, and they performed best, with the most accurate and precise estimates of hazard values using c gradational shading with isolines. The results suggest that visualisation of hazard data on a map can influence the information that people take away. Modified from Thompson et al. (2015)

make interpretations about hazard degree (less/more) when reading the sequential colour scheme map. In addition, more than two-thirds of survey participants self-reported that the colour scheme influenced the level of hazard they perceived from the map (Thompson et al. 2015).

Similarly, while red-yellow-green "stoplight" colour schemes are applied in a number of volcanic hazard maps around the world, Olson and Brewer (1997) and Jenny and Kelso (2007) warn that red-and-green colour schemes may introduce problems for colour vision deficient map readers. Up to $8 \%$ of males have some form of colour-vision deficiency, with difficulty distinguishing between red and green colours being the most common type (Delepero et al. 2005). To this population, the highest (red) and lowest (green) hazard areas may appear the same colour and cause confusion. To assist map makers in choosing appropriate colour schemes for maps, Harrower and Brewer (2003) developed ColorBrewer (www.ColorBrewer.org), a researchbacked tool for selecting map colour schemes with appropriate hue, saturation, and contrast to enhance visualisation of map information and prevent potential issues for colour vision deficient users.

Many of the challenges associated with visually designing volcanic hazard maps are faced in other fields of hazard and risk research, such as 
(a) Red-to-blue diverging hue colour scheme

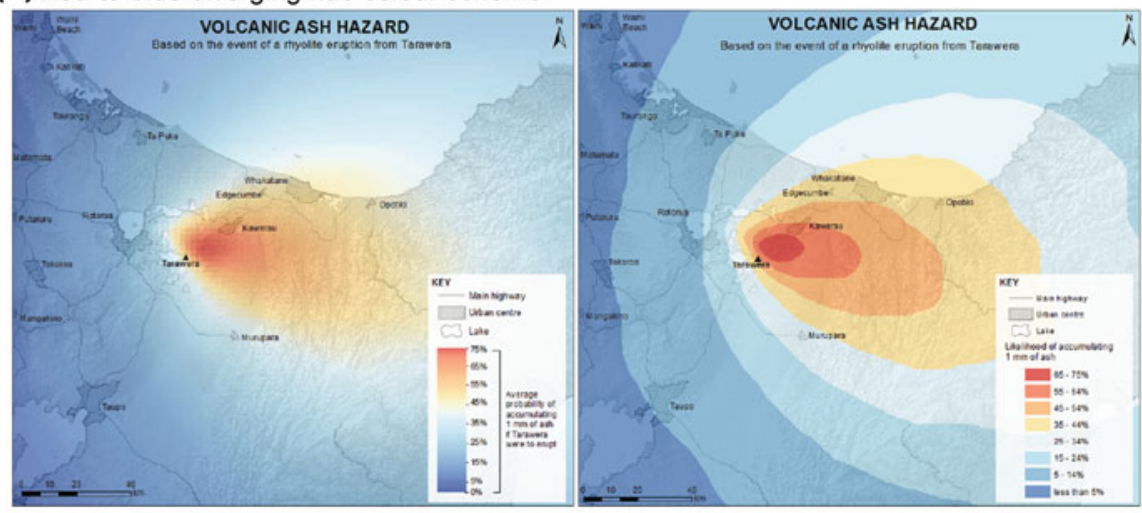

(b) Red-to-yellow sequential hue colour scheme

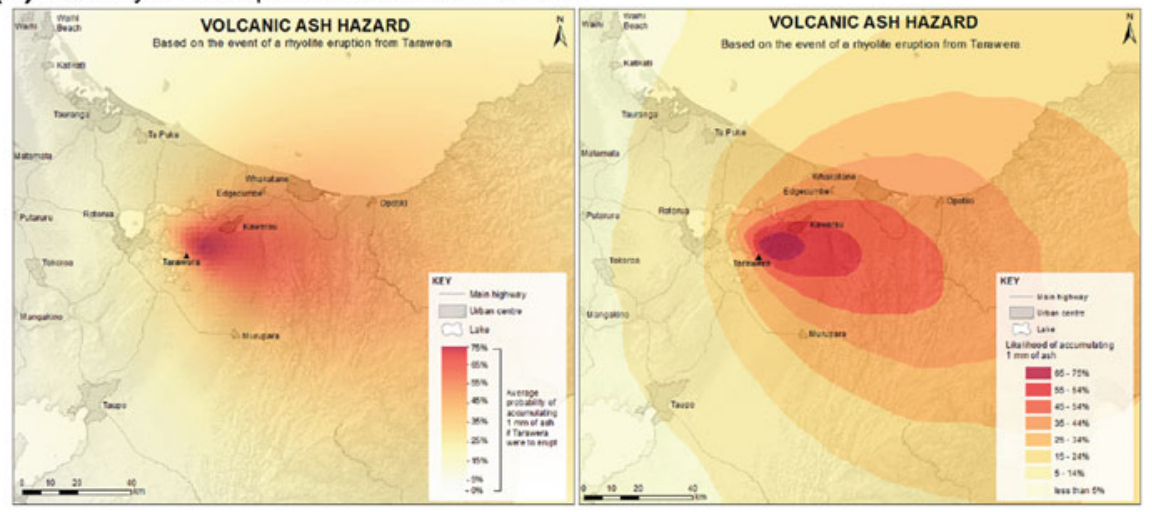

Fig. 7 Two hazard map colour schemes tested by Thompson et al. (2015). Participants were more likely to discuss a hazard state (e.g., present or absent) when viewing a the red-to-blue diverging hue colour scheme, and were more likely to discuss hazard degree when viewing $\mathbf{b}$ the red-to-yellow sequential hue colour scheme map. Modified from Thompson et al. (2015) wildfire (e.g., Cheong et al. 2016), hurricane (e.g., Broad et al. 2007; Sherman-Morris et al. 2015), flooding (e.g., Strathie et al. 2015), sea level rise (e.g., Retchless 2014), and health (e.g., Severtson and Myers 2013). For example, researchers have found that visual design of wildfire hazard maps can influence people's interest and engagement with the hazard information and also how they use it to make decisions about evacuation (Cao et al. 2016; Cheong et al. 2016). Similarly, visual design has been found to influence emotional and behavioural responses to tornado warning maps (Ash et al. 2014). Visualising and communicating uncertainty in geospatial data also remains an ongoing challenge across many different fields (Aerts et al. 2003; Spiegelhalter et al. 2011; Kinkeldey et al. 2014). As work in volcanic hazard map design continues to evolve, it is important to consider lessons learned from research and experience in these diverse fields, and drawn upon them to help inform and guide investigations of volcanic hazard communication.

In addition, contributions from cognitive science research can add new dimensions to understanding how visual design and visual perception of volcanic hazard maps can influence hazard interpretation and decision-making. For example, Hegarty (2011) summarises sixteen "principles of effective graphics" based on decades of cognitive science research into visual-spatial displays. Such principles, such as the relevance principle (Kosslyn 2006), which proposes that visual displays should present no 
more or no less information than is needed by the audience, could help inform approaches to visual design of volcanic hazard maps. Investigations of weather map reading performance suggests that considering such graphic principles in map design can affect visual processing of map information (Hegarty et al. 2010; Fabrikant et al. 2010). Similarly, Patterson et al. (2014) propose six "leverage points" for augmenting human cognition through information visualisations, which also are likely to have relevancy for map design. For example, they suggest that certain visual design approaches can help capture visual attention and also guide and focus visual search for information.

\subsection{Visualising Hazard in Different Formats}

Although the 2-dimensional plan view paper map remains a common and useful visualisation method in hazard mapping, volcanic hazard concepts can be mapped and visualised in many other ways. For example, modern geovisualisation and geographic information system (GIS) techniques, such as interactive interfaces (Çöltekin et al. 2009; Roth 2013) will play a significant role in shaping the future of hazard map communication. Interactive and $3 \mathrm{D}$ visualizations can add new dimensions to natural hazard and risk maps, through providing location-aware, user-centred data, although further research about these emerging technologies is needed to better understand the way they affect hazard and risk communication (Lonergan and Hedley 2015).

As improved workflows and accessibility of such methods continue to be developed, new opportunities will arise for communicating volcanic hazard in innovative and engaging ways. In a study at Mount Hood volcano in Oregon, USA, Preppernau and Jenny (2015) tested new methods of visualising lahar hazard using 3-dimensional (3D) oblique perspective base maps with isochrones that represented lahar travel time. They found that participants preferred 3D isochrone lahar hazard maps to traditional plan view contour maps, and that participants' performed better in interpreting terrain and evacuation routes with the 3D displays. Recent advancements in visual technology, such as eye-gaze trackers (devices that can be used to record a readers' eye movement across a visual or graphic), can also enable new forms of insight into map reading behaviour, visual attention, and understanding (e.g., Çöltekin et al. 2009; Meyer et al. 2012; Hegarty et al. 2010).

Innovative visualisations can also be developed with traditional, low-technology approaches. Hands-on, bottom-up, community-led participatory mapping exercises, in which tangible objects such as paper, pens, paint, and stones are used to visually represent and contextualise interrelationships between hazards and society, can help foster important dialogue about natural hazards and risk (Chambers 2008; Cadag and Gaillard 2012). For example, Cadag and Gaillard (2012) outline how participatory 3D mapping (P3DM) was used as an integrative tool for disaster risk reduction in Masantol, a small municipality on the island of Luzon in the Philippines. They found that collaboratively building a physical, 3D geographic model of place empowered the community to engage in constructive dialogue about hazard and risk. Such approaches also offer a way to integrate scientific and local knowledge in a way that is tangible and meaningful for many different people in the community, from government officials to school students (Cadag and Gaillard 2012).

\section{Volcanic Hazard Maps into the Future}

Volcanic hazard maps have transformed over the past several decades due to advances in hazard analysis methods, lessons learnt through past crises, and ongoing interdisciplinary research into how audiences engage and interact with hazard maps. Modern volcanic hazard maps will continue to evolve into the future as digital technologies, GIS, social media, citizen science, and globalisation have a growing impact on science communication and disaster management 


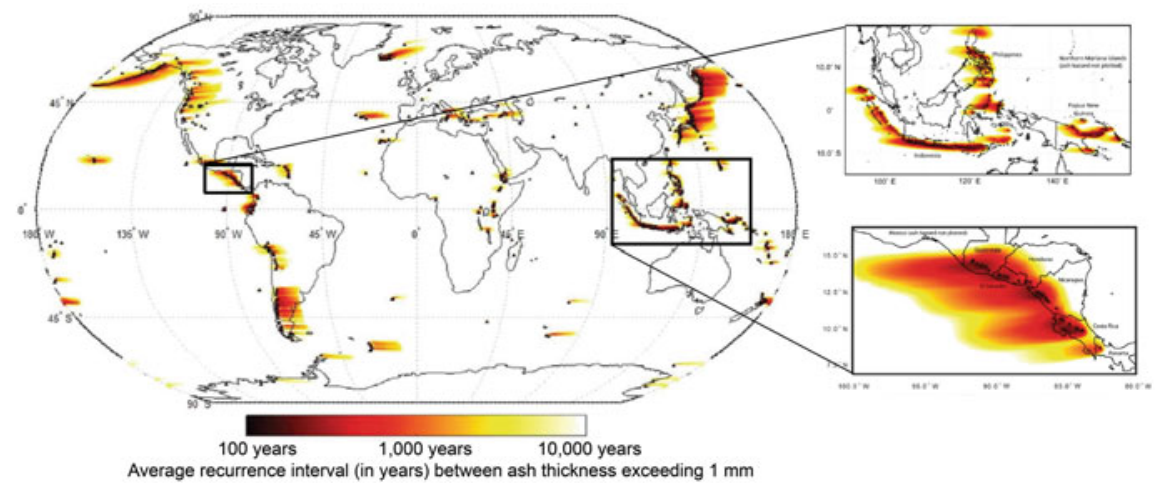

Fig. 8 Probabilistic volcanic hazard map showing global volcanic ash fall hazard. The map, which was produced for the UNISDR 2015 Global Assessment Report, is based on large-scale quantitative modelling, and shows

(e.g., Webley and Watson this volume, Kuhn et al. this volume). In 2015, one of the first global volcanic hazard maps was created as part of the UNISDR (United Nations Office for Disaster Risk Reduction) Global Assessment Report (Jenkins et al. 2015; Fig. 8). The map represents the growing global collaboration effort in volcanic hazard analysis, as well as the expanding capabilities of hazard modelling and computation. Collaborative international online volcanology networks, such as Vhub (www.Vhub. org; Palma et al. 2014), local online hubs, such as wikis (Leonard et al. 2014), and interactive online tools for volcanic hazard assessment, such as G-EVER (Tsukuda et al. 2012), are helping to facilitate data-sharing and improve access to hazard modelling, enabling new levels of engagement and access to tools and information for map-making and design.

While visual design of hazard maps will continue to evolve with innovation of new technologies and hazard mapping approaches, hazard map audiences will also evolve. As globalisation and population growth continues, hazard map audiences will dynamically shift and become more diverse. For example, growth in volcano tourism could lead to higher numbers of tourists and non-native speakers in hazardous areas, and these populations are likely to have different perceptions of hazard and risk than local audiences (Bird et al. 2010). Future work exploring differences in the information needs and cultural average recurrence interval (in years) between accumulating ash thicknesses exceeding $1 \mathrm{~mm}$. Modified from Jenkins et al. (2015)

communication styles within and among these diverse audiences will be important for understanding how to adapt and grow approaches to volcanic hazard knowledge exchange.

Interdisciplinary research is becoming increasingly embraced within the field of volcanic hazard and risk (Barclay et al. 2008), and future volcanic hazard maps should continue to work towards integrating new interdisciplinary concepts from research fields such as sociology, communications, human factors, geography, design, and psychology to develop intuitive designs which maximise visual cues, minimise cognitive load, and increase the effectiveness of visual communication. Integrating tacit knowledge from relevant areas of practice (e.g., emergency management, national parks, conservation) in addition to theories and concepts from different areas of research can help ensure that volcanic hazard maps of the future are optimally designed in a way that makes them useful, usable, and used.

It is important to acknowledge that the case studies and research covered in this chapter rely principally on work and experiences published in the academic literature, and are not comprehensive. There is a wealth of tacit knowledge on audience-map engagement and hazard communication gained from practice that is not captured in this summary. However, a key theme which emerges from the case studies and work reviewed in this chapter is that an audience-based, 
evidence-backed approach to visual design of hazard maps can help facilitate clear hazard communication. As with most communication approaches, hazard map design is not "one-size-fits all", and cannot be guided by a single universal framework or design solution. Nevertheless, hazard maps that: (A) consider the audience and their messaging needs, and (B) use evidence from interdisciplinary research and experience to inform visual map design based on these needs, can help communicate information in a way that is accessible and useful to those who need it. While available resources, target audiences, and volcanic setting will uniquely guide and shape this process for each map, adopting such an approach can help create end results that are grounded in meaningful communication goals.

\section{Summary}

Volcanic hazard maps that are designed based on both the needs of the audience and evidence from practice and research can help support clear and effective messaging of critical hazard information. Engaging with audiences to explore how they understand and create meaning from hazard maps can foster constructive multi-way dialogue about volcanic hazards, and also help ensure that important messages are visually communicated in a way that is transparent and trusted by those potentially affected by a volcanic crisis. Although hazard maps represent just one component of a hazard assessment, their ability to comprise many types of information into a concise, visually salient graphic that can be shared across many types of media means that they are often used widely in crisis communication. Past volcanic crises across the world have underscored the important communication role of hazard maps, but have also highlighted the significant impact that visual design has on this exchange.

Visual representation of hazard information on a map can influence the way that people engage with the information, as well as the messages that people take away, and decisions they make. Future work into the ways in which people read, process, and share visual information will open new opportunities for optimising volcanic hazard content for different audiences. This will continue to be important as advances in hazard modelling and visualisation technology introduce new ways of visually communicating hazard during a crisis. As the volcanology community works towards exploring new ways of developing and designing volcanic hazard maps, new levels of global collaboration through online data-sharing hubs will provide ways to connect, share, and integrate these emerging approaches. By considering audience needs and perspectives - how the information might be used, read, understood, and applied - hazard maps can be designed in a way that makes them accessible, relevant, and clear for the people who need them.

Acknowledgements The authors would like to acknowledge the many generations of volcanic hazard maps which have contributed valuable insight and knowledge regarding both the advantages and challenges of visually communicating volcanic hazard. The authors would also like to thank M Monsalve, $\mathrm{H}$ Murcia, and C Driedger for reviewing parts of this manuscript, and two anonymous reviewers for constructive and valuable comments on an earlier version of this chapter. MAT and JML gratefully acknowledge support from the New Zealand Earthquake Commission.

\section{References}

Aerts J, Clarke K, Keuper A (2003) Testing popular visualization techniques for representing model uncertainty. Cartogr Geogr Inf Sci 30:249-261. doi:10. 1559/152304003100011180

Ash KD, Schumann RL III, Bowser GC (2014) Tornado warning trade-offs: evaluating choices for visually communicating risk. Weather Clim Soc 6:104-118. doi:10.1175/WCAS-D-13-00021.1

Aspinall WP, Loughlin SC, Michael FV, Miller AD, Norton GE, Rowley KC, Sparks RSJ, Young SR (2002) The Montserrat Volcano observatory: its evolution, organization, role and activities. In: Druitt TH, Kokelaar BP (eds) The eruption of Soufrière Hills Volcano, Montserrat, from 1995 to 1999. Geological Society of London Memoirs, vol 21, pp 71-91

Barclay J, Haynes K, Mitchell T, Solana C, Teeuw R, Darnell A, Crosweller S, Cole P, Pyle D, Lowe C, Fearnley C, Kelman I (2008) Framing volcanic risk communication within disaster risk reduction: finding 
ways for the social and physical sciences to work together. Geol Soc Lond Spec Publ 305:163-177. doi:10.1144/SP305.14

Bertin J (1983) Semiology of graphics (trans: Berg WJ). University of Wisconsin Press, Madison, WI

Bird D, Gisladottir G, Dominey-Howes D (2010) Volcanic risk and tourism in southern Iceland: implications for hazard, risk and emergency response education and training. J Volcanol Geoth Res 189:33-48. doi:10.1016/j.jvolgeores.2009.09.020

Bostrom A, Löfstedt RE (2003) Communicating risk: wireless and hardwired. Risk Anal 23:241-248. doi:10.1111/1539-6924.00304

Brewer CA (1994) Color use guidelines for mapping and visualization. In: MacEachren AM, Taylor DRF (eds) Visualization in modern cartography. Elsevier, Tarrytown, New York, pp 123-147

Broad K, Leiserowitz A, Weinkle J, Steketee M (2007) Misinterpretations of the "Cone of Uncertainty" in Florida during the 2004 hurricane season. Bull Am Meteorol Soc 88(5):651-667

Cadag J, Gaillard J (2012) Integrating knowledge and actions in disaster risk reduction: the contribution of participatory mapping. Area 44:100-109. doi:10. 1111/j.1475-4762.2011.01065.x

Calder ES, Wagner K, Ogburn SE (2015) Volcanic hazard maps. In: Loughlin SC, Sparks S, Brown SK, Jenkins SF, Vye-Brown C (eds) Global volcanic hazards and risk. Cambridge University Press, Cambridge UK

Cao Y, Boruff B, McNeill I (2016) Is a picture worth a thousand words? Evaluating the effectiveness of maps for delivering wildfire warning information. Int $\mathbf{J}$ Disaster Risk Reduct 19:179-196. doi:10.1016/j.ijdrr. 2016.08.012

Carrasco M (2011) Visual attention: the past 25 years. Vis Res 51:1484-1525. doi:10.1016/j.visres.2011.04.012

Chambers R (2008) Revolutions in development inquiry. Earthscan, London

Cheong L, Bleisch S, Kealy A, Tolhurst K, Wilkening T, Duckham M (2016) Evaluating the impact of visualization of wildfire hazard upon decision-making under uncertainty. Int J Geogr Inf Sci 1-28. doi:10.1080/ 13658816.2015.1131829

Çöltekin A, Heil B, Garlandini S, Fabrikant S (2009) Evaluating the effectiveness of interactive map interface designs: a case study integrating usability metrics with eye-movement analysis. Cartogr Geogr Inf Sci 36:5-17. doi:10.1559/152304009787340197

Cronin S, Gaylord D, Charley D, Alloway BV, Wallez S, Esau JB (2004) Participatory methods of incorporating scientific with traditional knowledge for volcanic hazard management on Ambae Island, Vanuatu. Bull Volc 66:652-668. doi:10.1007/s00445-004-0347-9

Daron J, Lorenz S, Wolski P, Blamey R, Jack C (2015) Interpreting climate data visualisations to inform adaptation decisions. Climate Risk Manage 10:1726. doi:10.1016/j.crm.2015.06.007

Delepero WT, O’Neill H, Casson E, Hovis J (2005) Aviation-relevant epidemiology of color vision deficiency. Aviat Space Eviron Med 76:127-133
Domke D, Perimutter D, Spratt M (2002) The primes of our times? An examination of the "power" of visual images. Journalism 3:131-159. doi:10.1177/ 146488490200300211

Doyle EE, McClure J, Johnston DM, Paton D (2014) Communicating likelihoods and probabilities in forecasts of volcanic eruptions. J Volcanol Geoth Res 272:1-15. doi:10.1016/j.jvolgeores.2013.12.006

Driedger C, Ramsey D, Faust L (in preparation) Following the tug of the audience-from complex to simplified hazard maps at Cascade Range volcanoes. Front Volcanol Spec Issue Volc Hazard Assess

Ekse W, Burkhardt F, Kloes D, Driedger CL, Faust L, Nelson D (2015) Are you ready for an eruption? Mount Baker and Glacier Peak. Accessed 24 Sept 2016 at: http://www.dnr.wa.gov/programs-and-services/ geology/geologic-hazards/volcanoes-and-lahars\#volcanopreparedness-posters

Fabrikant SI, Hespanha SR, Hegarty M (2010) Cognitively inspired and perceptually salient graphic displays for efficient spatial inference making. Ann Assoc Am Geogr 100:13-29. doi:10.1080/00045600903362378

Fearnley CJ, McGuire WJ, Davies G, Twigg J (2012) Standardisation of the USGS volcano alert level system (VALS): analysis and ramifications. Bull Volc 74(9):2023-2036. doi:10.1007/s00445-012-0645-6

Finucane ML, Alhakami A, Slovic P, Johnson SM (2000) The affect heuristic in judgments of risks and benefits. J Behav Decis Mak 13(1):1-17

Gaillard J-C, Dibben C (2008) Volcanic risk perception and beyond. J Volcanol Geoth Res 172:163-169. doi:10.1016/j.jvolgeores.2007.12.015

GNS Science (2005) Volcanic hazards at Tongariro (map). Wellington, NZ

GNS Science (2012) Te Maari Eruption Phenomena (map). Wellington, NZ

Harrower M, Brewer CA (2003) ColorBrewer.org: an online tool for selecting colour schemes for maps. Cartogr J 40:27-37. doi:10.1179/00087040323500 2042

Haynes K, Barclay J, Pidgeon N (2007) Volcanic hazard communication using maps: an evaluation of their effectiveness. Bull Volc 70:123-138. doi:10.1007/ s00445-007-0124-7

Haynes K, Barclay J, Pidgeon N (2008) The issue of trust and its influence on risk communication during a volcanic crisis. Bull Volc 70:605-621. doi:10.1007/ s00445-007-0156-z

Hegarty M (2011) The cognitive science of visual-spatial displays: implications for design. Top Cogn Sci 3:446-474. doi:10.1111/j.1756-8765.2011.01150.x

Hegarty M, Smallman H, Stull A, Canham M (2009) Naïve cartography: how intuitions about display configuration can hurt performance. Cartographica 44(3):171-186. doi:10.3138/carto.44.3.171

Hegarty M, Canham M, Fabrikant S (2010) Thinking about the weather: how display salience and knowledge affect performance in a graphic inference task. J Exp Psychol Learn Mem Cogn 36:37-53. doi:10. 1037/a0017683 
Jenkins SF, Wilson TM, Magill CR, Miller V, Stewart C, Marzocchi W, Boulton M (2015) Volcanic ash fall hazard and risk: technical background paper for the UNISDR 2015 global assessment report on disaster risk reduction. Global Volcano Model and IAVCEI

Jenny B, Kelso N (2007) Color design for the color vision impaired. Cartogr Perspect 61-67. doi:10.14714/ CP58.270

Johnston DM, Lai MS, Houghton BF, Paton D (1999) Volcanic hazard perceptions: comparative shifts in knowledge and risk. Disaster Prev Manag 8:118-126. doi:10.1108/09653569910266166

Jolly AD, Jousset P, Lyons JJ, Carniel R (2014a) Seismo-acoustic evidence for an avalanche driven phreatic eruption through a beheaded hydrothermal system: an example from the 2012 Tongariro eruption. J Volcanol Geoth Res 286:331-347. doi:10.1016/j. jvolgeores.2014.04.007

Jolly GE, Keys H, Procter JN, Deligne NI (2014b) Overview of the co-ordinated risk-based approach to science and management response and recovery for the 2012 eruptions of Tongariro volcano, New Zealand. J Volcanol Geoth Res 286:184-207. doi:10. 1016/j.jvolgeores.2014.08.028

Kinkeldey C, MacEachren AM, Schiewe J (2014) How to assess visual communication of uncertainty? A systematic review of geospatial uncertainty visualisation user studies. Cartogr J 51:372-386. doi:10.1179/ 1743277414Y.0000000099

Kokelaar BP (2002) Setting, chronology and consequences of the eruption of Soufrière Hills Volcano, Montserrat (1995-1999). In: Druitt TH, Kokelaar BP (eds) The eruption of Soufrière Hills Volcano, Montserrat, from 1995 to 1999. Geological Society of London Memoirs, vol 21, pp 1-44

Kosslyn SM (2006) Graph design for the eye and mind. Oxford University Press, New York

Leonard G, Johnston D, Paton D et al (2008) Developing effective warning systems: ongoing research at Ruapehu volcano, New Zealand. J Volcanol Geoth Res 172:199-215. doi:10.1016/j.jvolgeores.2007.12.008

Leonard GS, Stewart C, Wilson TM, Procter JN, Scott BJ, Keys HJ, Jolly GE, Wardman JB, Cronin SJ, McBride SK (2014) Integrating multidisciplinary science, modelling and impact data into evolving, syn-event volcanic hazard mapping and communication: a case study from the 2012 Tongariro eruption crisis, New Zealand. J Volcanol Geoth Res 286:208232. doi:10.1016/j.jvolgeores.2014.08.018

Leone F, Lesales T (2009) The interest of cartography for a better perception and management of volcanic risk: from scientific to social representations: the case of Mt. Pelée volcano, Martinique (Lesser Antilles). J Volcanol Geoth Res 186:186-194. doi:10.1016/j. jvolgeores.2008.12.020
Lester PM (2014) Visual communication: images with messages, 6th edn. Wadsworth, Cengage Learning, Boston, MA

Lloyd R (2011) Understanding and learning maps. In: Dodge M, Kitchin R, Perkins C (eds) The map reader: theories of mapping practice and cartographic representation. Wiley, Hoboken, NJ

Lonergan C, Hedley N (2015) Navigating the future of tsunami risk communication: using dimensionality, interactivity and situatedness to interface with society. Nat Hazards 78:179-201. doi:10.1007/s11069-0151709-7

MacEachren A (1982) The role of complexity and symbolization method in thematic map effectiveness. Ann Assoc Am Geogr 72:495-513. doi:10.1111/j. 1467-8306.1982.tb01841.x

MacEachren A (1995) How maps work: representation, visualization, and design. Guilford Press, New York

Mendonça A, Delazari L (2014) Testing subjective preference and map use performance: use of web maps for decision making in the public health sector. Cartographica 49:114-126. doi:10.3138/carto.49.2. 1455

Meyer V, Kuhlicke V, Luther J, Fuchs S, Priest S, Dorner W, Serrhini K, Pardoe J, McCarthy S, Seidel J, Palka G, Unnerstall H, Viavattene C, Scheuer S (2012) Recommendations for the user-specific enhancement of flood maps. Nat Hazards Earth Syst Sci 12:1701-1716. doi:10.5194/nhess-12-1701-2012

Moebis A, Cronin SJ, Neall VE, Smith IE (2011) Unravelling a complex volcanic history from fine-grained, intricate holocene ash sequences at the Tongariro Volcanic Centre, New Zealand. Quatern Int 246:352-363. doi:10.1016/j.quaint.2011.05.035

Monmonier M (1996) How to lie with maps. University of Chicago Press, Chicago

Monzier M, Robin C (1995) Volcanic hazard map for Aoba Island. ORSTOM (Institut de recherche pour le developpement)

Mould D, Mandryk RL, Li H (2012) Emotional response and visual attention to non-photorealistic images. Comput Graph 36:658-672. doi:10.1016/j.cag.2012. 03.039

Nakamura Y, Fukushima K, Jin X, Ukawa M, Sato T, Hotta Q (2008) Mitigation systems by hazard maps, mitigation plans, and risk analyses regarding volcanic disasters in Japan. J Disaster Res 3(4):297-304

Nave R, Isaia R, Vilardo G, Barclay J (2010) Re-assessing volcanic hazard maps for improving volcanic risk communication: application to Stromboli Island, Italy. J Maps 6:260-269. doi:10.4113/jom.2010.1061

Olson JM, Brewer CA (1997) An evaluation of color selections to accommodate map users with color-vision impairments. Ann Assoc Am Geogr 87:103-134 
Palma J, Courtland L, Charbonnier S, Tortini R, Valentine GA (2014) Vhub: a knowledge management system to facilitate online collaborative volcano modeling and research. J Appl Volcanol 3:2. doi:10.1186/2191-5040-3-2

Parra E, Cepeda H (1990) Volcanic hazard maps of the Nevado del Ruiz volcano, Colombia. J Volcanol Geoth Res 42:117-127. doi:10.1016/0377-0273(90) 90073-O

Paton D (2003) Disaster preparedness: a social-cognitive perspective. Disaster Prev Manag 12(3):210-216. doi:10.1108/09653560310480686

Paton D, Smith L, Daly M, Johnston D (2008) Risk perception and volcanic hazard mitigation: individual and social perspectives. J Volcanol Geoth Res 172:179-188. doi:10.1016/j.jvolgeores.2007.12.026

Patterson RE, Blaha LM, Grinstein GG et al (2014) A human cognition framework for information visualisation. Comput Graph 42:42-58

Perkins C, Kitchin R, Dodge M (2011) Introductory essay: cognition and cultures of mapping. In: Dodge M, Kitchin R, Perkins C (eds) The map reader: theories of mapping practice and cartographic representation. Wiley, West Sussex, UK, pp 298-303

Perry SC, Blanpied ML, Burkett ER, Campbell NM, Carlson A, Cox DA, Driedger CL, Eisenman DP, Fox-Glassman KT, Hoffman S, Hoffman SM, Jaiswal KS, Jones LM, Luco N, Marx SM, McGowan SM, Mileti DS, Moschetti MP, Ozman D, Pastor E, Petersen MD, Porter KA, Ramsey DW, Ritchie LA, Fitzpatrick JK, Rukstales KS, Sellnow TL, Vaughon WL, Wald DJ, Wald LA, Wein A, Zarcadoolas C (2016) Get your science used-six guidelines to improve your products. USGS Circular 1419:37. doi:10.3133/cir1419

Pierson TC, Janda RJ, Thouret JC, Borrero CA (1990) Perturbation and melting of snow and ice by the November 1985 eruption of Nevado del Ruiz, Colombia, and consequent mobilization, flow and deposition of lahars. J Volcanol Geoth Res 41:17-66. doi:10. 1016/0377-0273(90)90082-Q

Pierson TC, Wood NJ, Driedger CL (2014) Reducing risk from lahar hazards: concepts, case studies, and roles for scientists. J Appl Volcanol 3:16. doi:10.1186/ s13617-014-0016-4

Potter SH, Jolly GE, Neall VE, Johnston DM, Scott BJ (2014) Communicating the status of volcanic activity: revising New Zealand's volcanic alert level system. J Appl Volcanol 3:12. doi:10.1186/s13617-014-0013-7

Preppernau C, Jenny B (2015) Three-dimensional versus conventional volcanic hazard maps. Nat Hazards 78:1329-1347. doi:10.1007/s11069-015-1773-Z

Rakow T, Heard CL, Newell BR (2015) Meeting three challenges in risk communication: phenomena, numbers, and emotions. Policy Insights Behav Brain Sci 2:147-156. doi:10.1177/2372732215601442
Retchless DP (2014) Sea level rise maps: how individual differences complicate the cartographic communication of an uncertain climate change hazard. Cartogr Perspect 77:17-32. doi:10.14714/CP77.1235

Robinson AH (1967) Psychological aspects of color in cartography. Int Yearb Cartogr 7:50-59

Robinson AH, Petchenik (1976) The nature of maps: essays toward understanding maps and mapping. University of Chicago Press, Chicago

Roth RE (2013) Interactive maps: what we know and what we need to know. J Spat Inf Sci 6:59-115. doi:10.5311/JOSIS.2013.6.105

Schelling J, Prado L, Norman D, Walsh T, Driedger C, Faust L, Westby L, Schroedel R, Lovellford P (2014) Are you ready for an eruption? Washington Department of Natural Resources. Accessed 24 Sept 2016 at: http://www.dnr.wa.gov/programs-and-services/geology/ geologic-hazards/volcanoes-and-lahars\#volcanopreparedness-posters

Servicio Geológico Colombiano (2015) Mapa de amenaza volcánica del Nevado del Ruiz. Escala 1:120,000 (http://www2.sgc.gov.co/Manizales/Imagenes/Mapasde-Amenaza/VNR/v3_img/Mapa_de_Amenaza_v32015-50.aspx)

Severtson D, Myers J (2013) The influence of uncertain map features on risk beliefs and perceived ambiguity for maps of modeled cancer risk from air pollution. Risk Anal 33:818-837. doi:10.1111/j.1539-6924. 2012.01893.x

Severtson D, Vatovec C (2012) The theory-based influence of map features on risk beliefs: self-reports of what is seen and understood for maps depicting an environmental health hazard. $\mathbf{J}$ Health Commun 17:836-856. doi:10.1080/10810730.2011.650933

Sherman-Morris K, Antonelli KB, Williams CC (2015) Measuring the effectiveness of the graphical communication of hurricane storm surge threat. Weather Clim Soc 7:69-82. doi:10.1175/WCAS-D-13-00073.1

Spiegelhalter D, Pearson M, Short I (2011) Visualizing uncertainty about the future. Science 333:1393-1400. doi:10.1126/science.1191181

Strathie, Netto, Walker GH, Pender (2015) How presentation format affects the interpretation of probabilistic flood risk information. J Flood Risk Manage. doi:10. $1111 /$ jfr3.12152

Sword-Daniels VL, Wilson TM, Sargeant S, Rossetto T, Twigg J, Johnston DM, Loughlin SC, Cole PD (2014) Consequences of long-term volcanic activity for essential services in Montserrat: challenges, adaptations and resilience. Geol Soc Spec Publ 39:471-488. doi:10.1144/M39.26

Thompson MA, Lindsay JM, Gaillard J (2015) The influence of probabilistic volcanic hazard map properties on hazard communication. J Appl Volcanol. doi:10.1186/s13617-015-0023-0 
Tsukuda E, Eichelberger J et al (2012) The G-EVER1 accord. G-EVER consortium. Retrieved from http://gever.org/en/accord/index.html

Tufte ER (1997) Visual explanations: images and quantities, evidence and narrative. Graphics Press, Chesire, CT, p 156

Open Access This chapter is licensed under the terms of the Creative Commons Attribution 4.0 International License (http://creativecommons.org/licenses/by/4.0/), which permits use, sharing, adaptation, distribution and reproduction in any medium or format, as long as you give appropriate credit to the original author(s) and the source, provide a link to the Creative Commons license and indicate if changes were made.
Voight B (1990) The 1985 Nevado del Ruiz volcano catastrophe: anatomy and retrospection. J Volcanol Geoth Res 44:349-386. doi:10.1016/0377-0273(90)90027-D

Wolfe JM, Horowitz TS (2004) What attributes guide the deployment of visual attention and how do they do it? Nat Rev Neurosci 5:495-501

The images or other third party material in this chapter are included in the chapter's Creative Commons license, unless indicated otherwise in a credit line to the material. If material is not included in the chapter's Creative Commons license and your intended use is not permitted by statutory regulation or exceeds the permitted use, you will need to obtain permission directly from the copyright holder. 